\title{
The Impact of Migration Processes on Development
}

\section{Dorin VACULOVSCHI ${ }^{1}$}

\begin{abstract}
In recent years, international migration has been growing rapidly and has reached over 272 million people or 3.5\% of the world's population, and 740 million people are considered internal migrants (IOM, 2020). Migration has become a defining feature of the modern global economy and the main factors behind its expansion are the processes of globalization itself, technical progress, the new economic order, etc. Since the early 1970s, governments in some countries have seen international migration as a major tool for economic development. Migration, especially labor migration, has become a defining element of economic development for the Republic of Moldova as well. Labor migration has become an important factor in combating poverty and increasing the welfare of the population of the Republic of Moldova. Moldova's economic growth over the last 20 years is due to remittances from migrant workers. There is a very close relationship between migration and Moldova's development prospects. The analysis of the impact of migration processes on the development perspectives of the Republic of Moldova, as well as the role of public authorities in the process of integrating migration into development strategies is the subject of this article.
\end{abstract}

Keywords: international labor migration, employment, human capital, remittances, sustainable development

JEL Code: J61

\section{Introduction}

The contemporary era can certainly be called an era of migration. In recent years international migration has reached over 272 million people or

\footnotetext{
${ }^{1}$ Dorin VACULOVSCHI is an associate professor at the Academy of Economic Studies form Moldova, Chisinau, Republic of Moldova, E-mail: dorinvaculovsky@yahoo.com. ORCID: 0000-0002-1500-0113
} 
$3.5 \%$ of the world's population, and 740 million people are considered internal migrants (IOM, 2020).

Migration is characteristic of virtually every state, and migration has become a defining feature of the modern global economy. The main factors behind its expansion are the very processes of globalization, technical progress, the new economic order, etc.

The importance of contemporary migration is linked not only to the number of people migrating, but also to the fact that migration is taking on increasingly diverse forms. Women are increasingly present in migration (the feminization of migration is taking place), many families are adapting to a transnational life, and a process of lifestyle change is taking place.

In today's conditions, labor migration is becoming an extremely important factor for the economic development of destination countries. The labor shortage caused by ageing processes, the huge differences in the level of development and welfare between countries of origin and destination, make destination countries increasingly attractive to migrants and their numbers are soaring. On the other hand, the economic underdevelopment and relative overpopulation of countries of origin are leading to an increased motivation for their inhabitants to leave their countries in the hope of securing a better living.

In the present period, for the Republic of Moldova, considered as a country of origin, the migratory phenomenon, especially labor emigration, has become a defining element of economic development as well as of human existence. Over the last 20 years the number of migrants has been on a continuous upward trend. Although official data estimate labor migration at around 350 thousand people in 2018 or about $30 \%$ of the country's human potential, numerous studies show that the scale of the phenomenon is much greater. According to World Bank estimates, in 2017 about 1.02 million people had left the country, of which about 300 thousand in Russia, 176 thousand in Italy, 158 thousand in Ukraine and 151 thousand in Romania (Spatari, 2019). The impact of migration on the social and economic situation in Moldova is significant. Labor migration has become an important factor in combating poverty and increasing the welfare of the population of the Republic of Moldova. And the economic growth that the Republic of Moldova is experiencing is due in particular to the remittances of emigrant workers. 
These have reached a level of about USD 1.5 billion (2020) constituting about $16 \%$ of the country's Gross Domestic Product (NBM, 2021).

At the same time, migrants, once they return home, bring not only money, but also new development ideas, knowledge and entrepreneurial skills that have been acquired as a result of migration.

As early as the early 1970s, governments in developed countries saw international migration as an important factor in economic development, implementing various models of circular labor migration that would benefit both their countries and the countries of origin. Today, the issue of integrating migration into development strategies is strongly promoted by most international organizations of the UN group and is on the agenda of governments in virtually every country.

This article aims to analyze the impact of migration processes on development processes in the Republic of Moldova in recent years. The article aims to highlight the impact of migration on various forms of development (economic development, community development, human development, etc.), as well as the extent to which it leads to changes in socio-human life and development goals in the Republic of Moldova.

\section{Literature review and data methodology}

For a more in-depth analysis of the research topic, a vast literature in the field, studies, monographs, articles, briefing notes, official data from governmental institutions concerned with promoting the integration of migration into development policies, etc., was analyzed. Such aspects as labor migration and its impact on development (Stalker, 2015), dual labor market and the role of labor migration in expanding the dual labor market (Piore, 2014), migration processes in the Russian Federation and the CIS Space (Mucomel \& Cheianu, 2013), and global trends in migration (International Organization for Migration, 2020) were taken into consideration etc.

In the process of analyzing the impact of migration on development processes in the Republic of Moldova, qualitative and quantitative research methods were used, such as: sociological observation, document analysis, and statistical data. Statistical data from the National Bureau of Statistics, the National Bank, as well as some data taken from various studies conducted in recent years were used. 


\section{The Model and Findings}

In order to highlight the effects of migration on development, it is usual to analyze the impact of the three types of transfers generated by migration, namely the transfer of people, the transfer of knowledge and know-how and the transfer of remittances. These transfers have a strong impact on economic development in both countries of origin and destination, and contribute significantly to the functionality of the economies of these countries.

\subsection{Impact of migration on labor market functionality in the Republic of Moldova}

Out of the many forms of migration, labor migration can probably be considered the most important, accounting for the largest share of all migration cases. The most representative developmental theory of international labor migration is neoclassical. According to this theory, international labor migration has the capacity to ensure labor market equilibrium in both countries of origin and destination and to create the conditions for sustainable development in both countries of origin and destination.

Countries of origin are often characterized by a shortage of capital and an excess of labor force that the economy of the given country cannot absorb. This excess of labor force is due to the pattern of enlarged reproduction of the population characteristic of the given countries, which leads to a strong increase in the number of the population and the labor force. Under these circumstances, international migration is a safe solution that helps to alleviate labor market imbalances in the countries of origin by reducing labor market pressure and reducing unemployment. On the other hand, the excess of labor force is a beneficial opportunity for investors to place their capital in these countries, thus helping to create new jobs and increase wage incomes. The experience of countries such as Mexico, the Philippines, India, China, etc. which have a longer tradition of international labor migration confirms this.

According to the Nexus study (Zwager \& Sintov,2014), the majority of long-term emigrants from the Republic of Moldova leave in order to find a more attractive job - about $89.5 \%$. Other relevant types of long-term migration can be considered migration for family reunification and migration for study purposes (Figure 1). 
Figure 1. Distribution of migrants by purpose, 2013, \%

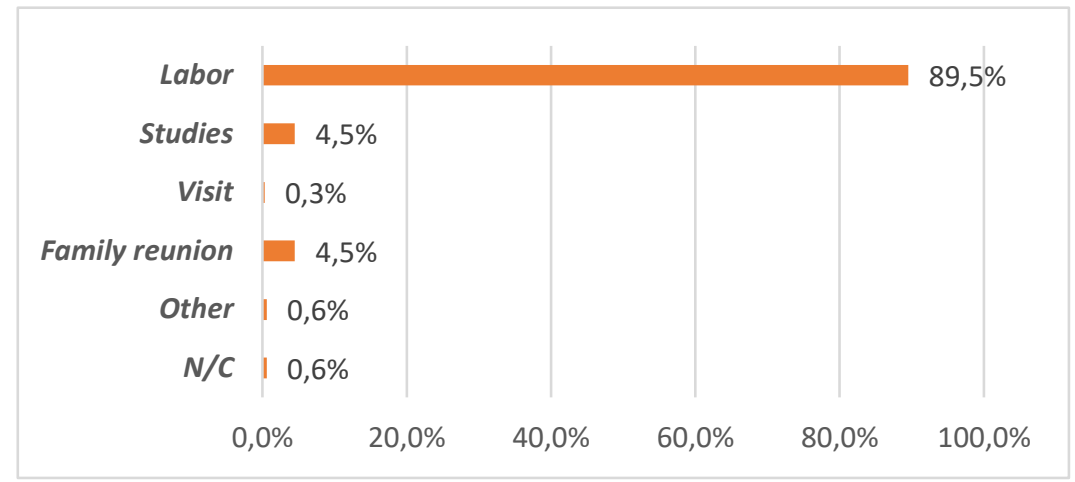

Source: Zwager, N., Sintov, R. (2014). Market Study: Innovation in circular migration - Migration and development in Moldova, Chisinau, IASCI

Referring to the situation on the labor market, Moldova is currently facing an extreme decline in employment levels. The employment rate has been around $40 \%$ and has remained at this level for several years. According to the Labour Force Survey data, in 2020 the employment rate was about 38.8\%, 2.0 p.p. lower than in the previous year, while the participation rate, stood at about $40.3 \%$, down 1.3 p.p. compared to the previous year (Figure 2).

Figure 2. Evolution of participation and employment rates

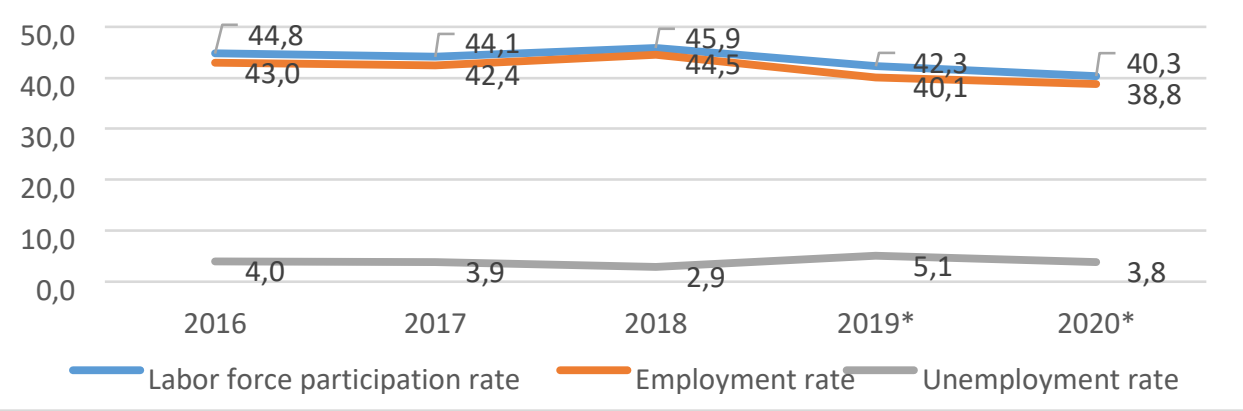

*From 2019 the Labor Force Survey is conducted according to a new survey design and under the revised definition of employment.

Source: National Bureau of Statistics (2020) (FM_2020.xlsx (live.com)

Alongside with decreasing level of employment, the unemployment rate is also falling. In 2020, the unemployment rate in the Republic of Moldova was $3.8 \%$. 
The decline in the occupational indicators takes place in the context of an accelerated growth in the inactive population (population outside the labor force) as well as in the number of people who do not want to work. According to the Labor Force Survey data, the number of people outside the labor force in 2020 amounted to 1283.6 thousand people, of which NEET youth ${ }^{1}$, respectively, 120.92 thousand people.

It can be noted that the population of the Republic of Moldova is not motivated to be present on the domestic labor market, preferring either to work abroad, to work in the informal economy, or activities other than labor. In 2020, the number of people who went abroad for work for less than one year, or intended to go abroad for work, was 241.5 thousand people (National Bureau of Statistics, 2021).

Some experts in the field, politicians and media sources try to demonstrate that the intensification of the migration is the main cause of the deterioration of occupational indicators, which realistically represents a major risk for the Republic of Moldova's economic development perspectives. Indeed, the decline in the volume of employment leads to the undermining of the social security system by increasing the economic dependency ratio, as well as to a labor force shortage emergence. Such a phenomenon has been observed in some countries in transition to a market economy that have successfully overcome the economic crisis.

However, the current reality in the Republic of Moldova is quite different. The massive exodus of working population is primarily due to the lack of real job opportunities, especially in rural areas, and to extremely low wage incomes that cannot ensure a decent standard of living. Despite the efforts of the central public authorities to improve the employment ${ }^{2}$ situation, the current economic climate is not yet capable of creating new, productive and attractive jobs that would motivate the population able to work to return home.

\footnotetext{
${ }^{1}$ The NEET (Not in Employment, Education or Training (NEET)) group are young people aged 15-29 who are not part of the employed population, are not studying/learning within the formal education system and do not participate in any courses or other training outside the formal education system.

2 Over the past years, several strategic documents have been developed focusing on increasing employment levels, such as the National Employment Strategy 2007-2015, the National Employment Strategy 2017-2021, the State Programme on the creation of 300 thousand jobs and raising the wage to USD 300, etc.
} 
In such situations, where people of working age cannot find their ways in their hometowns, and cannot ensure a decent living, labor migration would be the most beneficial solution. The situation is the most critical for rural localities, from where the majority of emigrants from the Republic of Moldova actually originate (around $69.6 \%$ in 2020) ${ }^{1}$. Indeed, in rural areas where the majority of the population is occupied in agriculture and the prospects for new jobs' creation are uncertain, opportunities to be hired for a job are practically non-existent.

Therefore, for the Republic of Moldova, international migration is, first and foremost, an essential source in ensuring a decent living for a large part of the country's inhabitants. In most cases, migrants were working prior to their departure: they either had paid jobs or had their own business. The main factors that led to people going abroad to work were low wages, non-secure jobs and working conditions and lack of opportunities to earn an adequate income for a decent living.

In most cases, leave abroad young people, people with a lower level of education and work experience. They are tempted to work abroad, because, for the same work provided, they get a higher net salary than in the Republic of Moldova. And the possibility of returning and reintegrating into the labor market at home is becoming less and less possible.

International labor migration can therefore be seen as an important factor in overcoming labor market imbalances for both sending and receiving countries. Migration flows become a mechanism for balancing globally the shortcomings in domestic markets and will lead to a lower wage level than before the intensification of the migration phenomenon in the developed country and respectively a higher wage in the poor country. In this way, migration also leads to a narrowing of the economic gap between the country of origin and the country of destination. The main effects of international labor migration are: Ensuring balance in the labor market; Maintaining a low level of pressure on the labor market; Making efficient use of available human potential; Ensuring demographic balance (both in countries of origin and destination countries); Increasing national income per capita.

\footnotetext{
${ }^{1}$ Author's estimations
} 
Therefore, it can be concluded that the first type of transfer - the transfer of people - is characteristic for the situation in the Republic of Moldova, ensuring the balance between supply and demand on the labor market.

\subsection{Impact of migration on the quality of human potential}

In the recent years, the technical progress, together with globalization processes, has led to an intensification of international labor migration flows. This increase has also been accompanied by the emergence of new types of migration such as intellectual migration, which is driven by the growing demand for a more skilled workforce in destination countries. With the development of the knowledge and innovation-based economy, practically all countries in the world are making great efforts to increase the level of education of their citizens and to provide the new developing economy with the necessary labor resources in order to meet the new demands of economic competitiveness. Certainly, every country has well-educated, creative thinking professionals capable of contributing to the modernization of the national economy. But their numbers are insufficient. This is confirmed by the shortage of qualified staff in the labor markets of destination countries, as reflected in the statements of recruitment agencies and employers on the selection of staff, especially highly qualified staff.

In this context, an optimal solution to reduce the shortage in this segment of the labor market would be to attract highly qualified personnel from abroad, especially as attracting foreign professionals also means bringing global experience and new knowledge into the country. It is noted that migration of unskilled workers is characteristic of all countries.

The phenomenon when skilled specialists leaving less developed countries for more developed ones is called 'brain drain'. This phenomenon began to be researched as early as the 1960s. The term 'brain drain' was launched to describe the emigration of engineers and scientists from Europe to the USA, which continues to be the main destination for highly skilled migrants nowadays. By the 1980s, the migrant typology was completed with professional or intellectual migrants, defined as skilled or highly skilled personnel moving from one country to another, often as members of international companies (Appleyard, 1991). This new category of migrants has been specifically defined to identify a variety of situations leading to a 
continuous increase in the number of such migrant workers, with a different impact compared to other types of migrants.

The category of "specialist" (professional worker) has become so important in international migration research that it has become necessary to divide it into subcategories: top managers; engineers; professionals; researchers; entrepreneurs; students. Each subcategory of skilled migrants determines its own reason for migration. Scientists may be motivated by some personal aspirations or scientific curiosity; for engineers, the main factors are salary levels or working conditions, while for entrepreneurs the main motivation is to increase income.

This type of transfer is also characteristic of the situation in the Republic of Moldova. International migration is important for migrant workers, including for the cultivation of an entrepreneurial culture. However, one of the main causes of the economic crisis is the lack of entrepreneurship, which was suppressed in the most brutal way during the socialist economy. Statistical data show that at the moment in the Republic of Moldova, the share of the employed population with the status of employer in the total employed population is very low and represents only $0.4 \%$. For this reason, the work and entrepreneurial skills that migrant workers cultivate in the countries of destination with a high level of economic development and can apply on their return are extremely important for Moldova's development prospects.

However, the majority of migrant workers are still employed in unskilled jobs, for which, in fact, there is the greatest labor shortage. Usually, these jobs are also called 3D (from the terms dirty, dangerous, difficult that characterize jobs in the secondary sector) (Stalker, 2015), and are deemed acceptable by migrant workers. No matter how low the wages for these jobs are, they still exceed the level of wages in the home country.

The main question here would be to what extent countries of origin do benefit or lose from the movement of highly skilled human capital. Various studies show that international migration can benefit not only destination countries but also countries of origin. However, the 'brain drain' is thought to reduce economic growth as sending countries lose important human capital and investment in education.

On the other hand, research on migration describes another phenomenon related to human capital, namely the process of "brain waste", which occurs 
when skilled professionals migrate to destination countries to provide lowerskilled labor services, which can lead in the long run to the degradation of human capital. In fact, a waste of human capital can also occur when the skilled labor force, remaining at home, cannot fully perform. However, human capital, like physical capital, has the property of depreciation, requiring permanent 'depreciation' investment. If skilled labor is not used, it loses its skills anyway. The emigration of skilled labor can therefore be seen at the same time as the preservation of its potential.

Diversification of the forms of movement of skilled migrant workers abroad has led to the emergence of the concepts of 'brain circulation' or 'brain exchange' as well as 'brain gain'. These concepts have emerged to analyze nonpermanent intellectual migration. Labour migration of researchers is a sure way to establish sustainable international contacts, to include scientists in the global intellectual labor market, and last but not least, it is a prerequisite for the development of science worldwide. The positive effect of the labor migration of specialists will come when the "brain drain" turns into a "brain circulation".

According to this phenomenon, returning migrants could make visible contributions to the economic growth of their country of origin, as the returnee would bring with him/her new work experiences, new technological ideas, specific to advanced countries. Brain circulation is justified by the fact that it is much cheaper to borrow a technology from outside the country than to reinvent the whole thing, from scratch, inside the country.

It is undeniable that the development of science in contemporary conditions is closely linked to the phenomenon of mobility. It is precisely the increase in mobility that has become an important factor contributing to the advancement of innovation. In this sense, the mobility of scientists is seen as a tool for improving the quality and productivity of scientists and research teams.

Mobility thus becomes a mechanism for knowledge dissemination, contributing to the promotion and development of new research areas, including interdisciplinary ones, and to the broadening of knowledge and skills horizons.

\subsection{Impact of remittances on Moldova's development}

Transfers of financial resources made by migrant workers are the third type of transfer, which can be considered as the most important in the development of the Republic of Moldova. 
Given that most international migration is labor migration, it brings in significant financial flows which in turn contribute to the welfare of the population. In 2020, the volume of remittances reached USD 1,486.74 million (or 16\% of GDP). This amount of money can be even higher if remittances through informal channels are taken into account (Figure 3).

The significant increase in the remittance flows since 2000 has been visibly correlated with a commensurate development in economic growth and the standard of living of many families in the Republic of Moldova, while also constituting a visible source for the development of businesses in the country and the creation of new jobs. Migration can be seen as a reliable way of combating poverty. Indeed, the remittances generated by migration lead to increased welfare for many families or households of emigrants.

\section{Figure 3. Money transfers from abroad to individuals (gross basis)}

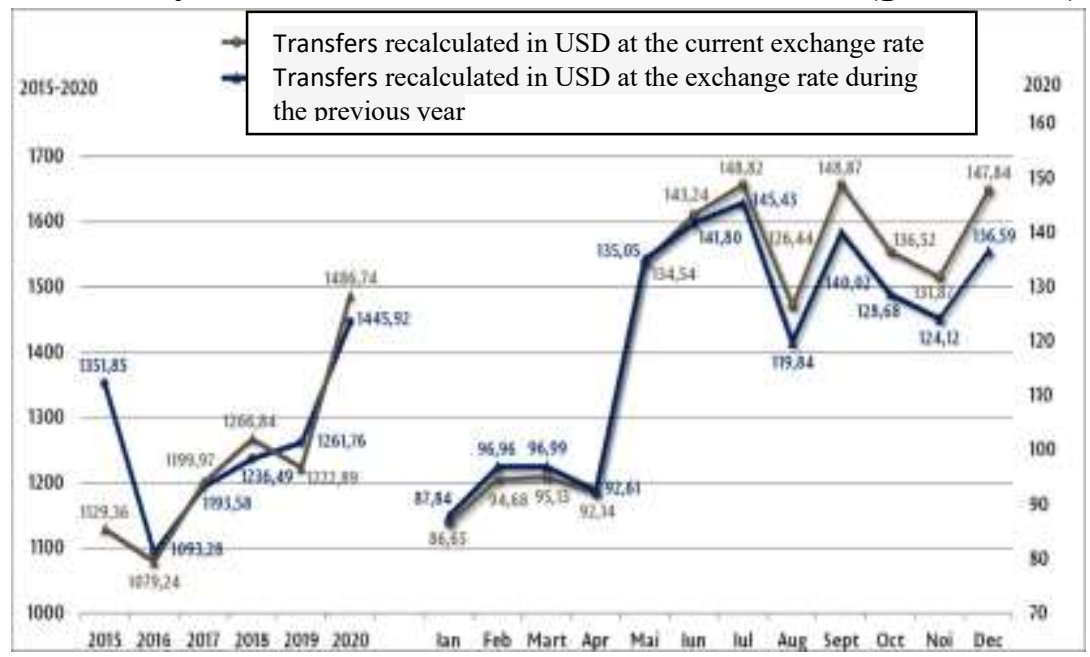

Source: data from National Bank of Moldova (2020)

The Household Budget Survey shows that the remittances are an important source of escape from poverty for the population of the Republic of Moldova. Thus, remittances from abroad in 2020, on average, accounted for $12.9 \%$ of total income or 0.5 percentage points more than in 2019 .

In the context of rising incomes, poverty levels have been reduced. Over the last few years, they have been halved (Figure 4). 
Figure 4. Absolute poverty rate (\%)

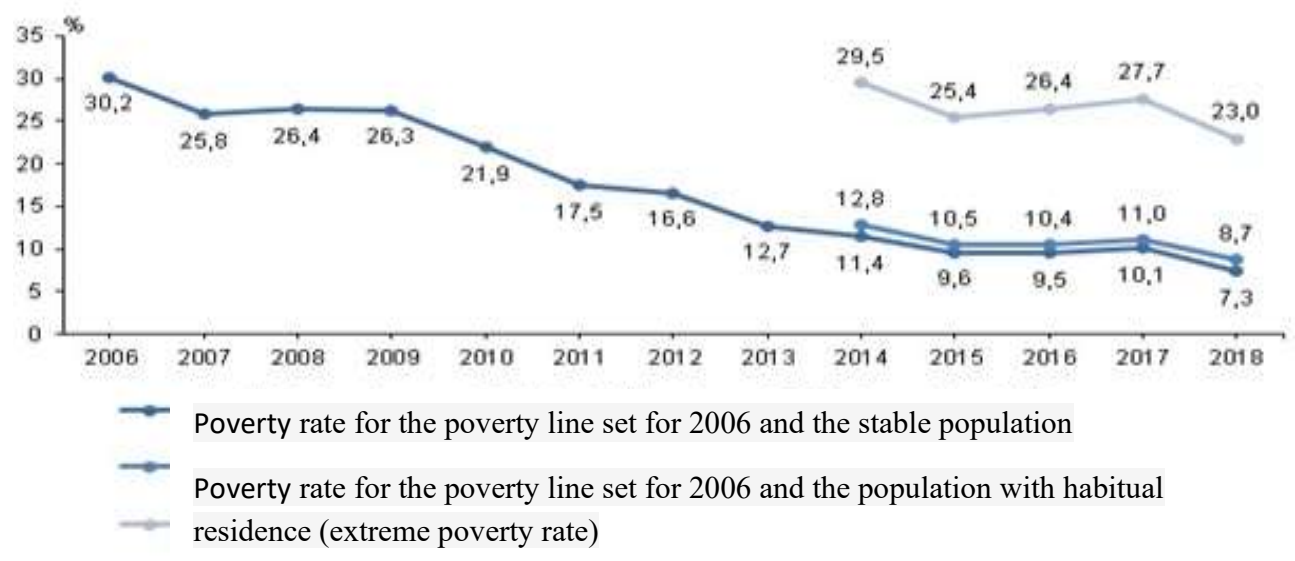

Source: National Bureau of Statistics (2020)

In 2014 the poverty rate in the Republic of Moldova was $11.4 \%$, twice lower than 5 years ago. Since 2015 the poverty line is calculated according to a new methodology (in 2019 the poverty line was 2,095.1 lei, compared to 1150 lei in 2014), which resulted in setting the poverty level at 25.2\%) (NBS, 2020).

Strategic development documents have recognized the importance of remittances for development. In the recent years, the issues of labor migration and remittances have started to have a more visible presence on the government agenda through the implementation of the "PARE 1+1" program of the Moldovan Organisation for Developing SMEs, which can have a real effect on the process of creating new jobs.

\section{Conclusions}

It can be concluded that international migration through the three types of transfers has an interventionist character and a strong impact on economic development. Migrant workers are potential job creators without private or public investment from the national economy. The transfer of foreign currency by migrant workers from abroad can be considered one of the great advantages of international migration, which has an impact on the national currency in terms of the evolution of the national currency exchange rate on the foreign exchange market. 
International migration is important for cultivating an entrepreneurial culture, especially for countries in transition to a market economy such as the Republic of Moldova. One of the main causes of the economic crisis in these countries is the lack of entrepreneurial spirit, which was most brutally suppressed during the socialist economy.

In fact, international labor migration brings benefits as well as risks. National economies characterized by high international labor migration become vulnerable to external shocks and build up a consumption-based development model. And the attractiveness of the country of origin for potential investors is too high, as it is also determined by other factors shaping the investment climate, such as the business environment, economic legislation, social infrastructure, the quality of the labor force, the capacity of markets, etc.

Migration processes are therefore neither good nor bad. They are a compensatory factor, mitigating economic and social imbalances and not a negative impact on the development of demographic processes.

\section{References}

Appleyard, R.T., (1991). International Migration: Challenge for the Nineties. Geneva: IOM, 84 p.

International Organization for Migration (2020). World migration report 2020. wmr_2020_en.pdf

International Centre for Migration Policy Development (ICMPD), (2013). Manual for migration training course. https://www.icmpd.org/ file/download/48316/file/Migration\%2520and\%2520Development $\% 2520 \mathrm{Po}$ licies\%2520and\%2520Practices_\%2520A\%2520mapping\%2520study $\% 252$ 0of $\% 2520$ eleven $\% 2520$ European $\% 2520$ countries $\% 2520 \% 2526 \% 2520$ the $\%$ 2520European\%2520Commission.pdf

Mucomel, V1., Cheianu, A. D. (2013). Moldovans in the Russian Federation: socio-economic profile and policy challenges, Study cycle „Mapping the Moldovan diaspora”, Chisinau, SocoPolis „Research and Consulting Center", 2013

National Bank of Moldova (2020). Money transfers from abroad made in favour of individuals through banks of the Republic of Moldova in the third quarter of 2020.https://www.bnm.md/en/content/money-transfers-abroadmade-favour-individuals-through-banks-republic-moldova-third-2 
National Bureau of Statistics (2021). Labour force in the Republic of Moldova employment and unemployment. https://statistica.gov.md/ public/files/publicatii_electronice/Forta_de_munca/AFM_2021.pdf National Bureau of Statistics (NBS) (2020). The level of poverty in the Republic of Moldova in 2019. https://statistica.gov.md/ newsview.php? $1=$ en \&id $=6865 \& \mathrm{idc}=168$

Piore, M.J., (2014), The dual labor market: Theory and implicatons, In D.B.

Grusky, K. R. Weisshaar (Eds.), Social Stratification, Routledge, 1196. Spatari, M., Guga, St. (2019). The situation of employees in the Republic of Moldova. A structural crisis, Chisinau, Friedrich-Ebert Foundation, 2019, Syndex_-_Situuatia_Salariatilor_din_Republica_Moldova_O_ Criza_Structurala_1_.pdf (fes.de)

Zwager, N., Sintov, R. (2014). Market Study: Innovation in circular migration - Migration and development in Moldova, Chisinau, IASCI, 2014.

Сталкер П., (2015). Международная миграция, М.Книжный клуб, 2015.

Acknowledgement: This article was elaborated within the project Jean Monnet Chair in EU Studies and Migration, implemented with support of the ERASMUS+ programme of the European Union (ref. nr. 620774-EPP-12020-1-MD-EPPJMO-CHAIR). The support granted by the European Commission for the elaboration of this publication is not a content approval, which only reflects the opinions of the authors, and the Commission can not be held accountable for any use of the information contained in this. 